\title{
Kontrol Lengan Robot yang Meniru Pergerakan Tangan untuk Inspeksi Objek yang Mengandung Gas Berbahaya
}

\author{
Wahyu Satrio Prayogo, Muhammad Rivai, Fajar Budiman \\ Departemen Teknik Elektro, Fakultas Teknologi Elektro \\ Institut Teknologi Sepuluh Nopember (ITS) \\ E-mail: muhammad_rivai@ee.its.ac.id
}

\begin{abstract}
Abstrak-Beberapa tahun terakhir ini banyak sekali teror bom yang ada di Indonesia, hal tersebut menyebabkan ketidaknyamanan orang dalam melakukan aktifitas sehari-hari di tempat umum. Untuk itu pada penelitian ini telah dibuat suatu lengan robot yang dapat dikendalikan berdasarkan pergerakan lengan manusia secara wireless. Pergerakan lengan dideteksi oleh sensor IMU MPU6050. Sensor ini dapat mendeteksi perubahan posisi pada sumbu $\mathrm{x}$, y dan $\mathrm{z}$, sehingga lengan robot dapat bergerak sesuai dengan perubahan posisi dari lengan operator. Pergerakan gripper dideteksi oleh sensor flex yang diletakkan pada jari operator, sehingga dari pergerakan jari dapat mengontrol pergerakan gripper yang ada pada lengan robot. Posisi lengan robot dikendalikan menggunakan kontrol Proporsional. Alat ini dilengkapi dengan sensor gas MQ2 yang digunakan sebagai sensor gas berbahaya. Mikrokontroler Arduino Uno digunakan mengakuisisi data sensor gas, menggerakkan motor servo dan sistem pengendali. Sedangkan mikrokontroler Arduino Nano digunakan untuk mengakuisisi data sensor IMU dan Flex. Dari hasil eksperimen menunjukkan bahwa nilai kesalahan posisi pada lengan robot untuk sumbu pitch dan yaw masing - masing sebesar $4 \%$ dan 0,2\%. Jarak maksimal modul Bluetooth dalam mengirimkan data adalah 5 meter tanpa terhalang apapun. Hasil dari rancang bangun lengan robot ini diharapkan dapat membantu pekerjaan manusia dan juga memperkecil resiko terluka akibat bahan peledak atau gas yang membahayakan manusia.
\end{abstract}

Kata Kunci-Lengan Robot, Mikrokontroler Arduino, Sensor IMU, Sensor Gas.

\section{PENDAHULUAN}

$\mathrm{B}^{\mathrm{E}}$ EBERAPA tahun terakhir dunia mengalami krisis dalam keamanan dan kenyamanan dalam beraktifitas di ruang publik. Hal tersebut dapat terjadi dikarenakan ada beberapa ulah kelompok tertentu yang memberikan teror berupa bom atau barang berbahaya lainnya yang diletakkan pada suatu tas yang mencurigakan, kemudian diletakkan tempat-tempat umum yang ramai dengan aktifitas manusia. Sudah banyak peristiwa yang telah terjadi yang dampaknya sangat merugikan, dari kerugian materil hingga hilangnya nyawa manusia karena terkena ledakan bom tersebut. Terdapat 6 peristiwa teror yang besar telah terjadi di Indonesia. Yang pertama yaitu bom Bali 1 yang terjadi pada tahun 2002 yaitu rentetan tiga peristiwa pengeboman terus-menerus yang terjadi pada malam hari tanggal 12 Oktober 2002. Kedua yaitu peristiwa ledakan bom JW Marriott pada tanggal 5 Agustus 2003 di kawasan Mega kuningan Jakarta.

Selama ini proses inspeksi barang berbahaya yang dilakukan oleh pihak berwajib hanya dengan menggunakan anjing atau dengan mengecek barang tersebut secara langsung. Proses penginspeksian tersebut akan menimbulkan resiko yang teramat besar bagi petugas maupun anjing yang digunakan untuk menginspeksi barang yang dicurigai. Sebagai contoh peristiwa yang telah menelan korban akibat bom buku pada tahun 2011 di Utan kayu Jakarta Timur.

Dari banyaknya peristiwa teror diatas maka pada penelitian ini dibuatlah sebuah prototype lengan robot yang dapat menginspeksi barang mencurigakan yang terdapat pada tempat umum. Robot ini akan bergerak sesuai dengan pergerakan lengan manusia yang dilengkapi dengan sensor gas yang dapat memberikan informasi adanya gas berbahaya.

\section{TEORI PENUNJANG}

\section{A. Sensor IMU MPU 6050}

MPU 6050 merupakan sensor 3 axis gyroscop dan 3 axis accelero, ditunjukkan pada Gambar 1. Sensor gyroscope menggunakan prinsip dasar MEMS (micro electro mechanical system). Ketika gyroscope bergerak maka akan menghasilkan tegangan output, sedangkan saat gyroscope diam maka tegangan akan konstan. Ketika gyroscope berputar searah jarum jam terhadap sumbu $\mathrm{Z}$ maka tegangan ouput berkurang (-Z), dan ketika gyroscope berputar berlawanan arah jarum jam maka tegangan output bertambah $(+\mathrm{Z})$.

Accelerometer merupakan sebuah sensor yang menghitung percepatan atau perubahan kecepatan. Accelerometer mengukur percepatan relative terhadap frame yang popular disebut G-force. Pada saat accelero diam yang searah dengan percepatan gravitasi, maka akan bernilai $1 \mathrm{~g}$ dan ketika accelero mendeteksi adanya sebuah percepatan maka g-force akan berubah.

Sensor MPU 6050 memiliki tegangan suplay 3,3V. Sensor ini dapat mengirimkan data dari accelero dan gyroscope dengan menggunakan komunikasi I2C SDA dan SCL. Untuk mengakses data dari MPU 6050 ini maka perlu dilakukannya pengaturan pada pengambilan data melalui I2C. Untuk mendapatkan data gyro dan accelero dari MPU6050 maka harus mengatur pin SDA SCL. Pertama pin SDA dan SCL diset HGH kemudian dengan mengakses alamat dari gyro dan accelero.

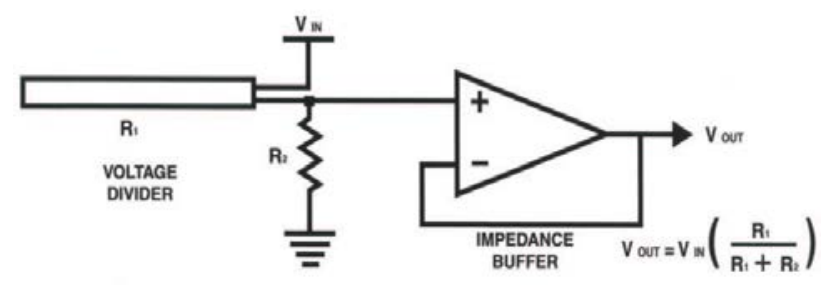

Gambar 1. Rangkaian dasar sensor flex. 


\section{B. Sensor Flex}

Sensor flex merupakan sebuah sensor fleksibel yang memiliki panjang 4,5 inch. Sensor flex menghasilkan suatu resistansi apabila ditekuk. Nilai resistansi dari sensor ini berubah seiring besarnya nilai sudut yang dibentuk[1]. Pada Gambar 1 menunjukkan rangkaian dasar dari sensor flex. Tegangan output dari sensor dapat dirumuskan seperti pada persamaan 1 .

$$
V_{\text {out }}=\frac{R_{2}}{R_{1}+R_{2}} x V_{\text {in }}
$$

\section{Sensor gas $M Q-2$}

MQ-2 adalah sensor semikonduktor untuk gas yang mudah terbakar. Bahan sensitif dari sensor gas MQ-2 adalah $\mathrm{SnO}_{2}$ yang mempunyai konduktivitas rendah di udara bersih. Ketika terdapat target gas yang mudah terbakar, maka konduktivitas sensor lebih tinggi seiring dengan meningkatnya konsentrasi gas. Sensor gas MQ-2 memiliki kepekaan yang tinggi terhadap LPG, Propana dan Hidrogen. Pada Gambar 2 menunjukkan karakteristik sensitivitas khas MQ-2. Sumbu ordinat adalah rasio resistensi dari sensor (Rs/Ro), absis adalah konsentrasi gas. Rs adalah resistensi sensor untuk gas yang berbeda, Ro adalah resistensi sensor dalam 1000ppm Hidrogen. Semua tes berada dalam kondisi uji standar. Pada Gambar 3 menunjukkan karakteristik suhu dan kelembaban yang khas untuk sensor ini[2].

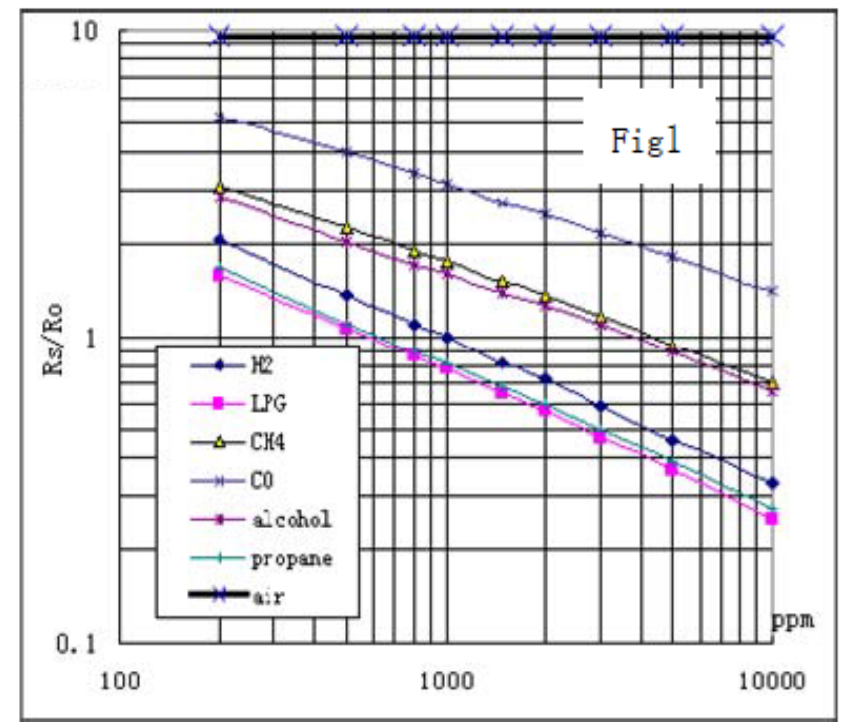

Gambar 2. Karakteristik sensitivitas sensor MQ-2.

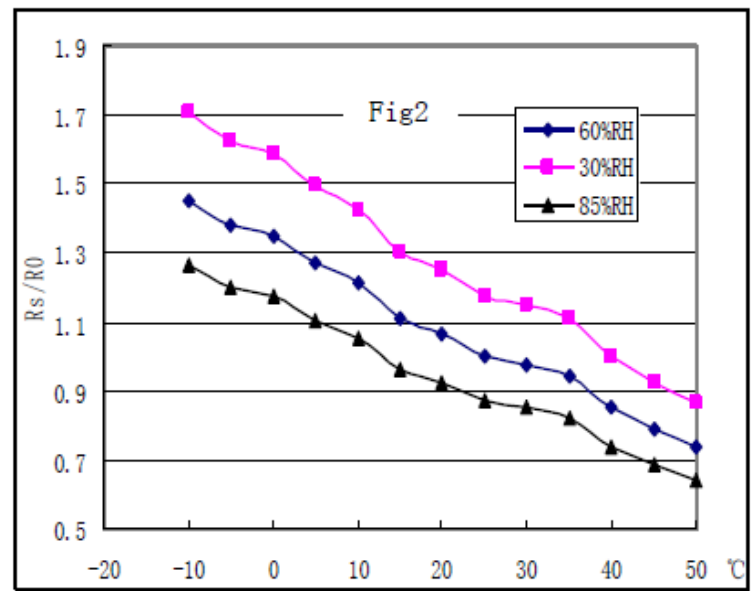

Gambar 3. Karakteristik suhu dan kelembaban sensor MQ-2.
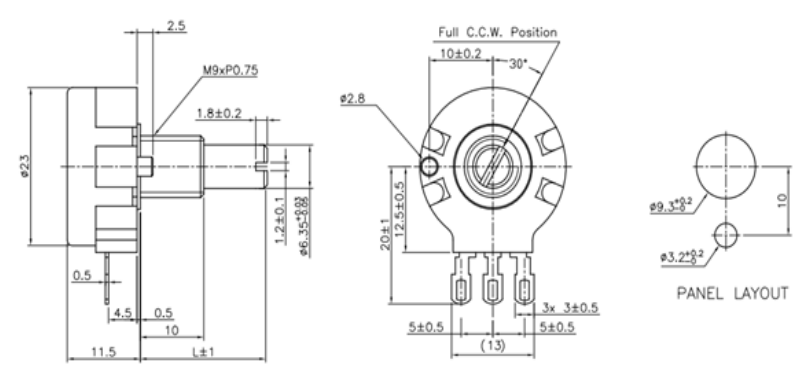

Gambar 4. Dimensi potensiometer.

\section{Sensor Posisi Potensiometer}

Potensiometer adalah resistor tiga terminal dengan sambungan geser yang membentuk pembagi tegangan yang dapat diatur. Jika hanya dua terminal yang digunakan (salah satu terminal tetap dan terminal geser), maka potensiometer berperan sebagai resistor variabel atau Rheostat. Potensiometer biasanya digunakan untuk mengendalikan piranti elektronik seperti pengendali suara pada penguat. Potensiometer dapat dioperasikan sebagai transduser. Dimensi dari suatu potensio dapat dilihat pada Gambar 4. Output potensiometer ini berupa resistansi yang linier sehingga dapat digunakan untuk mengukur perubahan posisi dari perubahan resistansi. Output dari potensiometer dapat ditunjukkan pada persamaan 2 .

$$
V_{\text {out }}=\frac{R_{1}}{R_{1}+R_{2}} x V_{\text {in }}
$$

\section{E. Metode Exponential Filter}

Filter eksponensial adalah filter yang melewatkan frekuensi rendah dan meredam frekuensi tinggi. Metode ini hanya memiliki satu parameter metode pengaturan. Metode ini membutuhkan penyimpanan hanya satu variabel keluaran sebelumnya. Diagram blok dari filter exponential dapat dilihat pada Gambar 5. Persamaan filter eksponensial dinyatakan pada persamaan 3.

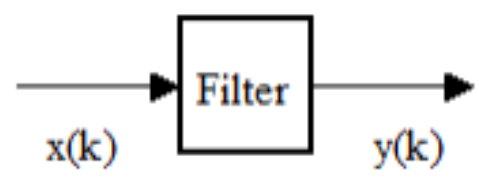

Gambar 5. Diagram blok exponential filter

$$
Y(k)=a * Y(k-1)+(1-a) * x(k)
$$

dimana $\mathrm{X}(\mathrm{k})$ data pembacaan sensor tiap satuan waktu, $\mathrm{Y}(\mathrm{k})$ output dari filter tiap satuan waktu, A adalah konstanta antara 0 sampai 1 , normalnya antara 0.8 dan 0.99 , (a-1) atau a terkadang dikenali dengan istilah "smoothing constant"[3], [4].

\section{F. Sistem Kontrol Closed Loop}

Sistem kontrol terbagi dua, yaitu sistem kontrol open loop dan kontrol closed loop. Sistem kontrol closed loop identik dengan sistem kontrol umpan balik dimana nilai dari keluaran akan ikut mempengaruhi pada aksi kontrolnya[3], [5]. Gambar 6 menunjukkan hubungan masukan dan keluaran dari sistem kontrol ini. Sistem closed loop ini digunakan untuk mengatur posisi dari motor servo yang ada pada lengan robot. Sehingga dengan menggunakan sistem closed loop diharapkan output dapat tetap terjaga pada setpoint yang diberikan. 


\section{PERANCANGAN SISTEM}

\section{A. Diagram Blok Fungsional Sistem}

Secara keseluruhan blok fungsional sistem pada sisi operator dan sisi lengan robot dapat dilihat pada Gambar 7 dan 8.

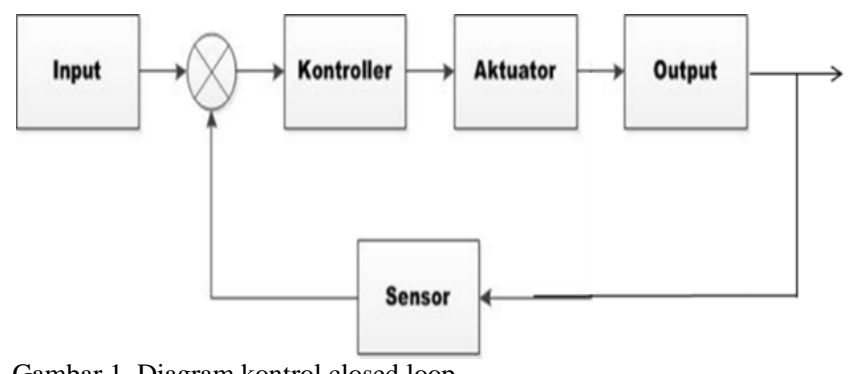

Gambar 1. Diagram kontrol closed loop.

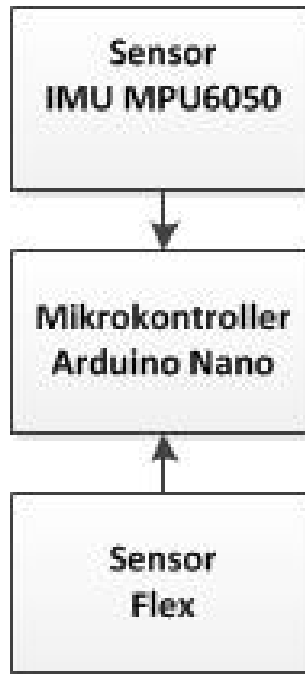

Gambar 7. Diagram blok sistem pada sisi operator.

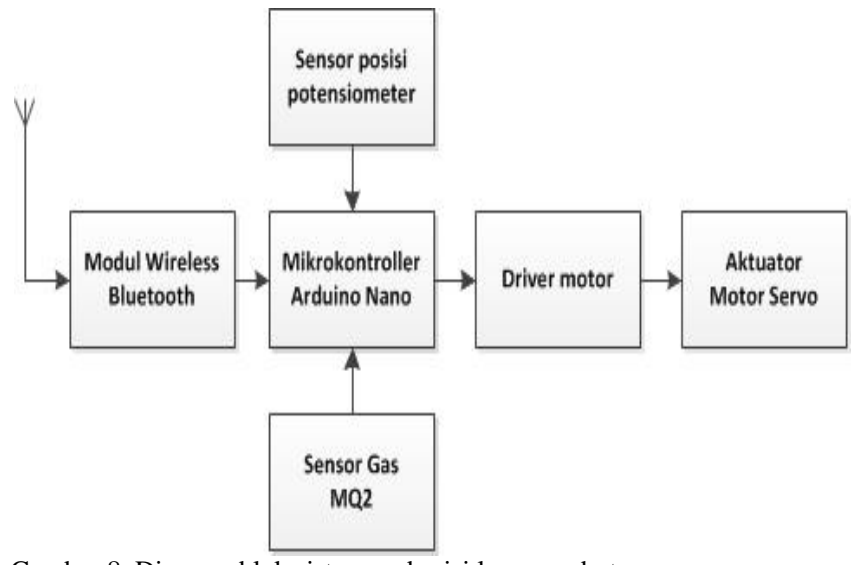

Gambar 8. Diagram blok sistem pada sisi lengan robot.

\section{B. Perancangan Mekanik Gripper dan Lengan Robot}

Pada perancangan gripper atau penggenggam ini direncanakan mampu bergerak 1 DOF dengan lebar sudut yang dapat dibuat sebesar 60 derajat. Dimensi dari gripper yaitu $10 \mathrm{~cm}$ x $3 \mathrm{~cm} \times 2,5 \mathrm{~cm}$. Desain 3D dari gripper dapat dilihat pada Gambar 9. Pada perancangan lengan robot digunakan bahan berupa akrilik dengan ukuran tebal 4mm. Lengan robot direncanakan mampu bergerak 2 DOF dengan jangkauan lengan maksimal $60 \mathrm{~cm}$. Dimensi dari lengan robot yaitu $30 \mathrm{~cm}$ x $30 \mathrm{~cm}$ x $45 \mathrm{~cm}$. Desain 3D dari lengan robot dapat dilihat pada Gambar 10.

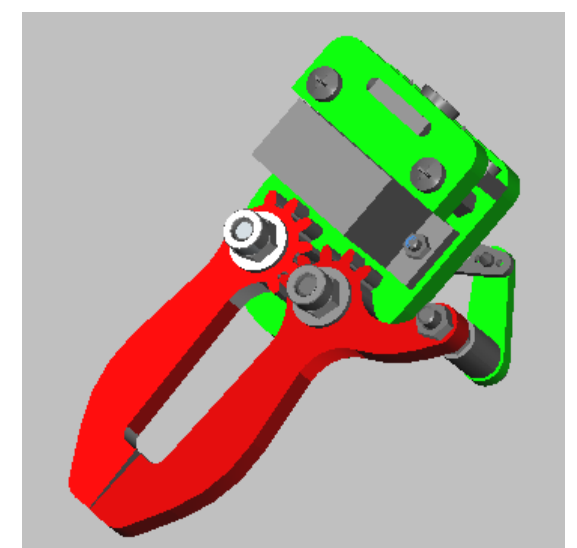

Gambar 9. Desain 3D gripper.

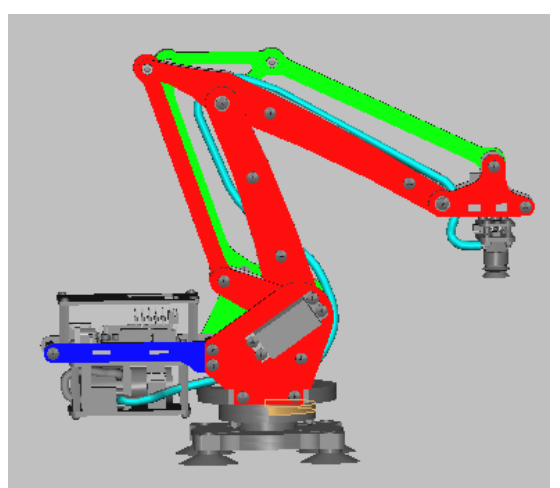

Gambar 10. Desain 3D lengan robot.

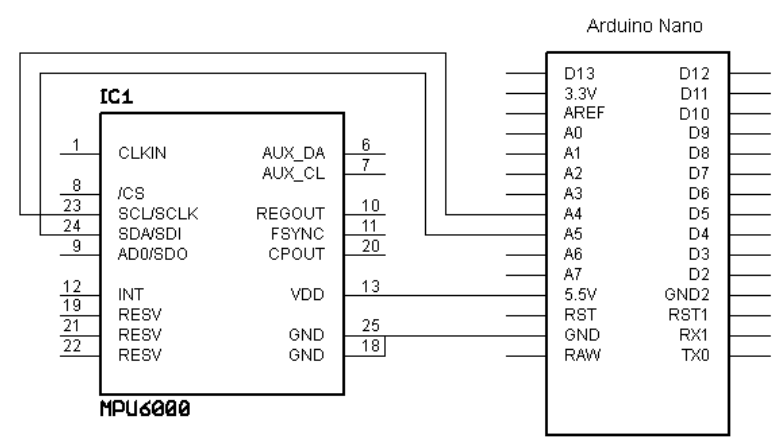

Gambar 11. Rangkaian sensor MPU6050.

\section{Perancangan Rangkaian Sensor MPU6050}

Pada perancangan rangkaian sensor MPU6050, pinout dari MPU6050 yang digunakan yaitu pin SDA, SCL, INT, VCC dan GND. Sedangkan pada sisi arduino nano digunakan pin A4 untuk SDA, A5 untuk SCL, D2 untuk INT kemudian VCC dan GND. Perancangan rangkaian MPU6050 dapat dilihat pada Gambar 11[6], [7].

\section{Perancangan Rangkaian Sensor Gas MQ-2}

Pada sensor gas MQ-2 terdapat 4 macam pin output, diantaranya yaitu pin VCC, GND, D0, dan A0. Untuk pin D0 merupakan output yang bernilai digital, sedangkan A0 merupakan pin output yang bernilai Analog. Rangkaian sensor gas MQ-2 dapat dilihat pada Gambar 12[8], [9].

\section{E. Perancangan Rangkaian Sensor Flex}

Output dari sensor flex ini berupa resistansi sehingga diperlukan resistor sebagai pembagi tegangan yang dapat dibaca oleh ADC dari arduino nano. Penambahan komponen op-amp digunakan apabila tejadi drop tegangan yang diakibatkan karena terlalu panjang kabel dari sensor menuju mikrokontroler. Op-amp yang digunakan LM358 dengan konfigurasi non-inverting amplifier. Pin yang digunakan 
arduino nano untuk membaca nilai ADC yaitu pada pin A1. Rangkaian sensor flex dapat dilihat pada Gambar 13.

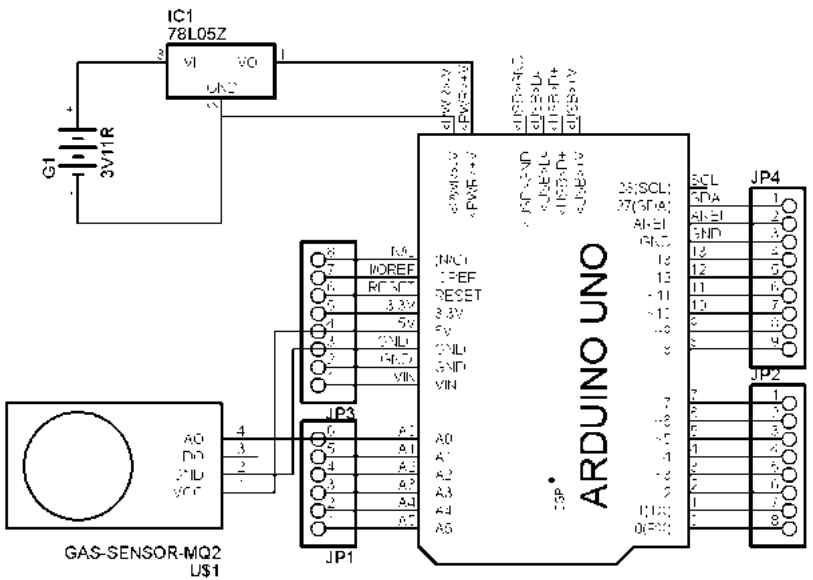

Gambar 12. Rangkaian sensor gas MQ-2.

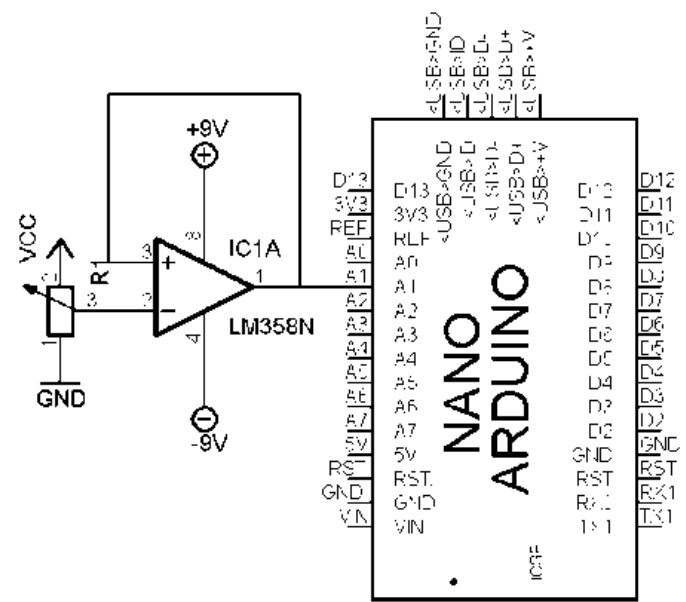

Gambar 13. Rangkaian Sensor Flex.

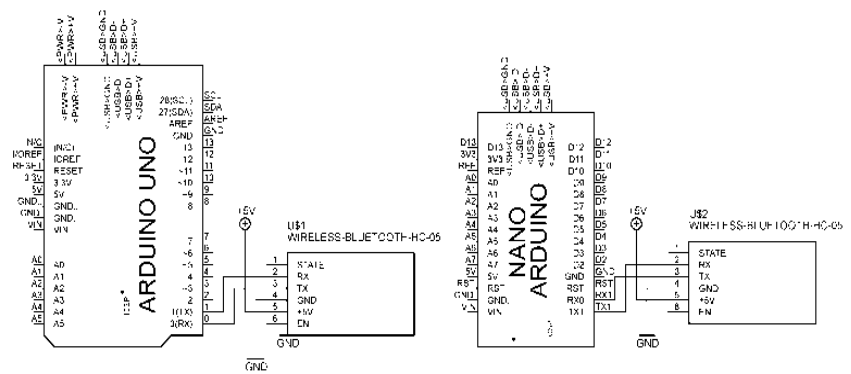

Gambar 14. Rangkaian komunikasi dengan Bluetooth HC-05.

\section{F. Perancangan Rangkaian Bluetooth HC-05}

Pada penelitian ini menggunakan 2 modul Bluetooth HC05 yang difungsikan sebagai master dan slave. Pin yang digunakan yaitu Tx, Rx, VCC, dan GND. Konfigurasi pin Tx dan Rx ini dihubungkan secara silang pada pin Arduino. Rangkaian modul komunikasi ini dapat dilihat pada Gambar 14.

\section{HASIL PENGUJIAN}

Dari perancangan keseluruhan sistem dapat direalisasikan lengan robot seperti yang di tunjukkan pada Gambar 15. Pengujian diperlukan untuk mengetahui kinerja sistem yang telah dibuat.

\section{A. Pengujian Sensor MPU6050}

Gambar 16 menunjukkan perbandingan antara nilai output MPU6050 sumbu yaw sebelum dan sesudah difilter, dimana garis biru menunjukkan nilai output sebelum di filter dan garis merah menunjukkan nilai output sesudah di filter. Sedangkan Gambar 17 menunjukkan perbandingan antara nilai output sensor untuk sumbu pitch. Setelah proses pemfilteran maka langkah selanjutnya adalah pengujian kesesuaian gerak dari motor servo. Hasil dari pengujian ini dapat dilihat pada Tabel 1.

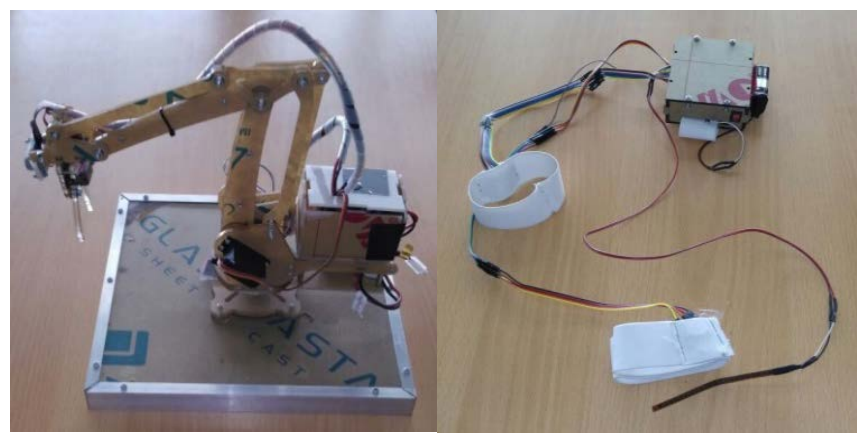

Gambar 15. Hasil realisasi lengan robot.

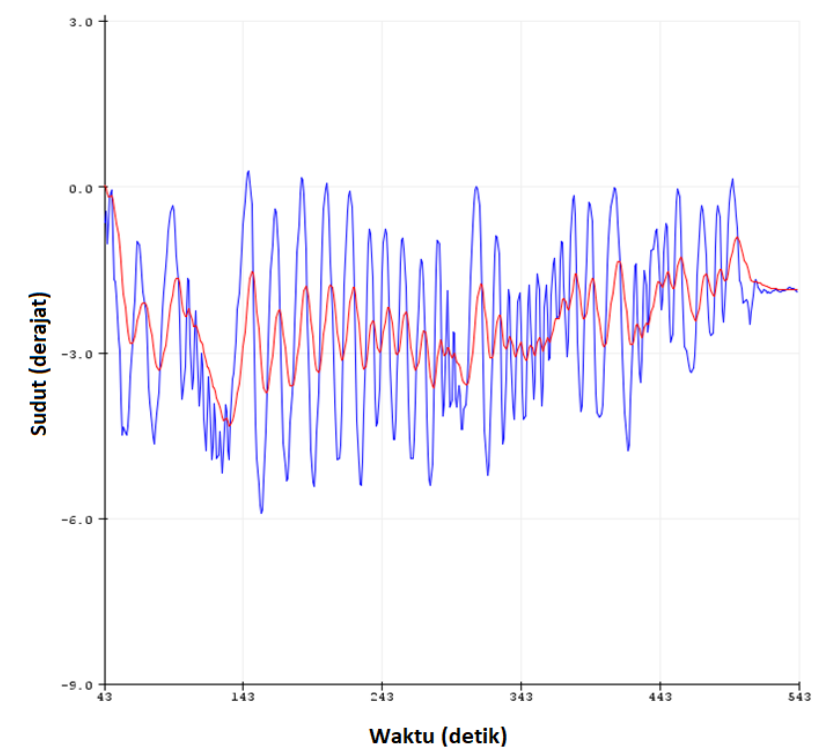

Gambar 16. Data yaw sebelum dan sesudah melewati filter.

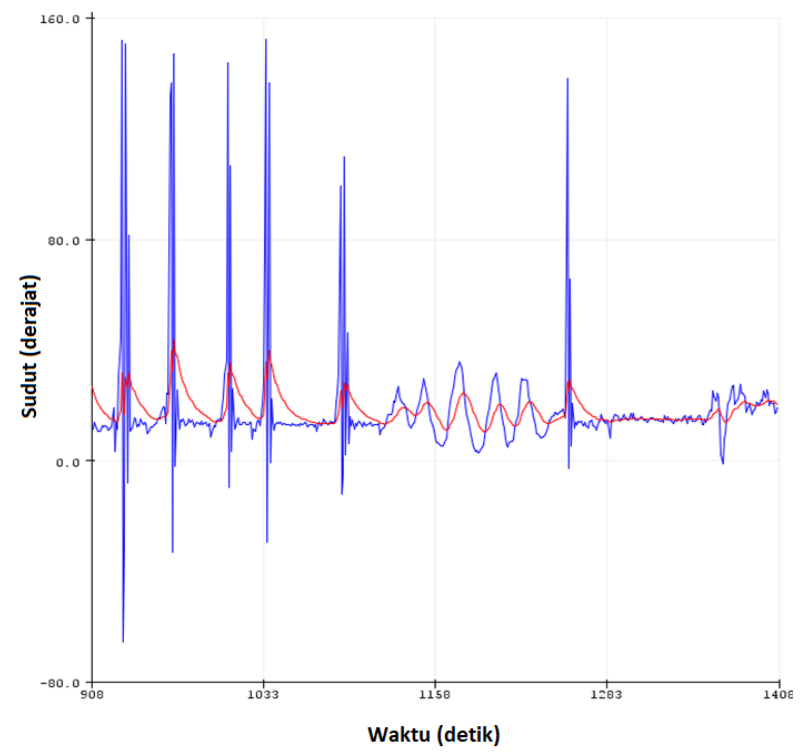

Gambar 17. Data Pitch sebelum dan sesudah melewati filter. 
Tabel 1.

Pengujian kesesuaian sudut pitch dan yaw

\begin{tabular}{ccccc}
\hline $\begin{array}{c}\text { Sudut Input } \\
\text { (derajat) }\end{array}$ & Pitch & Yaw & $\begin{array}{c}\text { Error } \\
\text { Pitch }\end{array}$ & Error Yaw \\
\hline 90 & 88 & 90 & 2,2 & 0 \\
80 & 79 & 80 & 1,2 & 0 \\
70 & 68 & 70 & 2,8 & 0 \\
60 & 57 & 60 & 5 & 0 \\
50 & 50 & 55 & 0 & 10 \\
40 & 41 & 40 & 2,5 & 0 \\
30 & 30 & 37 & 0 & 3,3 \\
20 & 23 & 20 & 15 & 0 \\
10 & 11 & 10 & 10 & 0 \\
0 & 0 & 0 & 0 & 0 \\
-10 & -9 & -10 & 10 & 0 \\
-20 & -20 & -20 & 0 & 0 \\
-30 & -30 & -32 & 0 & 6,6 \\
-40 & -38 & -40 & 5 & 0 \\
-50 & -46 & -50 & 8 & 0 \\
-60 & -56 & -63 & 6,6 & 5 \\
-70 & -68 & -75 & 2,8 & 7,1 \\
-80 & -76 & -80 & 5 & 0 \\
-90 & -87 & -90 & 3,3 & 0 \\
Error Rata-Rata & & & 4,1 & 0,2 \\
\hline \hline
\end{tabular}

\section{B. Pengujian Sensor Flex}

Tabel 2 menunjukkan hasil pengukuran sensor flex. Dapat dilihat bahwa rentang perubahan nilai ADC yaitu 105. Sedangkan perubahan sudut pada servo berkisar 60 derajat. Untuk mendapatkan konversi sudut maka diskalakan perubahan 105 menjadi 0 sampai 60 derajat.

\section{Pengujian Sensor Gas MQ2}

Gas yang digunakan untuk pengujian adalah butana. Proses pengambilan datanya adalah dengan menyemprotkan gas secara perlahan lalu dilihat data ADC yang terbaca pada serial monitor Arduino. Berikut data pengambilan dari sensor gas dapat dilihat pada Gambar 18.

Tabel 2.

Data pengujian sensor flex.

\begin{tabular}{ccc}
\hline \hline Sudut (derajat) & ADC & Sudut konversi \\
\hline 0 & 885 & 0 \\
10 & 855 & 10 \\
20 & 843 & 15 \\
30 & 836 & 30 \\
40 & 825 & 0 \\
50 & 810 & 0 \\
60 & 790 & 0 \\
70 & 781 & 0 \\
80 & 771 & 0 \\
90 & 760 & 0 \\
100 & 740 & 10 \\
110 & 738 & 10 \\
120 & 732 & 20 \\
130 & 710 & 20 \\
140 & 705 & 30 \\
150 & 690 & 30 \\
\hline \hline
\end{tabular}

Pemilihan nilai threshold didasarkan pada tingkat konsentrasi kepekatan suatu gas. Nilai threshold diambil saat sensor mulai mendeteksi adanya gas. Pada kondisi udara bersih nilai ADC terbaca 46, namun ketika mulai diberi gas nilainya menjadi 67. Sehingga penentuan threshold adalah 67. Pengujian sensor gas untuk indikator buzzer dapat dilihat pada Tabel 3.

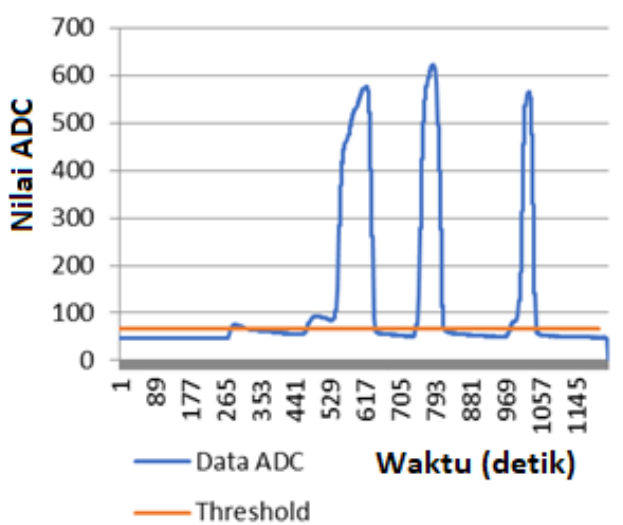

Gambar 18. Data pembacaan sensor MQ-2.

Tabel 3.

Data pengujian sensor gas MQ-2.

\begin{tabular}{cccc}
\hline \hline Tipe gas & ADC & Tegangan & Keterangan (buzzer) \\
\hline \multirow{6}{*}{ Butana } & 47 & 0 & Mati \\
& 67 & 0.33 & Nyala \\
& 127 & 0.62 & Nyala \\
& 315 & 1.54 & Nyala \\
& 502 & 1.96 & Nyala \\
& 734 & 2.85 & Nyala \\
& 818 & 4.59 & Nyala \\
& 857 & 4.19 & Nyala \\
& & & Nyala \\
\hline
\end{tabular}

Tabel 4.

Pengujian pengiriman data Bluetooth.

\begin{tabular}{cc}
\hline \hline Jarak (m) & Keterangan \\
\hline 1 & Tersambung \\
2 & Tersambung \\
3 & Tersambung \\
4 & Tersambung \\
5 & Tersambung \\
6 & Terputus \\
7 & Terputus \\
8 & Terputus \\
9 & Terputus \\
10 & Terputus \\
\hline \hline
\end{tabular}

\section{Pengujian Sistem Peringatan Jarak Aman}

Tujuan dari pengukuran dan pengujian jarak adalah mengetahui kemampuan dari modul Bluetooth dalam mengirimkan data. Cara pengambilan data yang digunakan yaitu dengan mengirimkan data untuk menggerakkan lengan robot. Kemudian dari lengan robot dilihat apakah pergerakan sesuai dengan pergerakan lengan operator, ditunjukkan pada Tabel 4 .

\section{KESIMPULAN}

Pada penelitian ini telah dihasilkan suatu lengan robot dengan dua derajat kebebasan yang dilengkapi dengan 1 gripper. Jangkauan maksimum dari lengan robot adalah 60 $\mathrm{cm}$. Pada lengan robot ini dilengkapi modul Bluetooth HC-05 yang digunakan sebagai transfer data dari operator menuju lengan robot. Jarak maksimal dari pengiriman data menggunakan modul Bluetooth adalah 5 meter. Proses penentuan sudut dari lengan robot ini menggunakan sensor MPU6050 yang diambil datanya pada sumbu pitch dan yaw. Dari hasil pengujian sensor tersebut didapatkan bahwa sensor mampu mendeteksi perubahan sudut pada sumbu pitch dengan error rata-rata sebesar 4,17\% sedangkan untuk 
sumbu yaw sebesar 0,2 \%. Lengan robot ini juga dilengkapi dengan sensor gas dengan tipe MQ-2 yang digunakan untuk mendeteksi adanya suatu gas yang berada disekitar lokasi lengan robot. Sistem akan mendeteksi adanya gas apabila pembacaan sensor gas melebihi nilai ambang tertentu dengan mengaktifkan indikator buzzer.

\section{DAFTAR PUSTAKA}

[1] A. A. Kusuma, "Tangan robot peniru gerak tangan manusia berbasis mikrokontroler,” Universitas Sanata Dharma, 2015.

[2] H. Avrilyantama, M. Rivai, and D. Purwanto, "Pengembangan robot hexapod untuk melacak sumber gas,” J. Tek. ITS, vol. 4, no. 1, pp. F12-F17, Mar. 2015.

[3] D. A. R. Kurniawan, M. Rivai, and R. Dikairono, "Sistem navigasi pada balon udara menggunakan GPS dan kontrol logika fuzzy,” $J$. Tek. ITS, vol. 5, no. 2, pp. A173-A178, Aug. 2016.
[4] R. Setiawan, Teknik Akuisisi Data. Yogyakarta: Graha Ilmu, 2008.

[5] F. A. Muhammad, M. Rivai, and S. Suwito, "Perancangan sistem stabilisasi kamera tiga sumbu dengan metode kontrol fuzzy untuk mobile surveillance robot,” J. Tek. ITS, vol. 5, no. 2, pp. A167-A172, Aug. 2016.

[6] "MPU-6000 and MPU-6050 Product Specification Revision 3.4 MPU-6000/MPU-6050 Product Specification,” 2013.

[7] A. Saifuddin, S. Sumardi, and D. Darjat, "Perancangan sistem kendali pergerakan arm manipulator berbasis sensor inertial measurement unit (IMU) dan sensor flex,” TRANSIENT, vol. 6, no. 3, pp. 424-431, Nov. 2017.

[8] A. N. Gustica, M. Rivai, and T. Tasripan, "Implementasi Sensor Gas pada Kontrol Lengan Robot untuk Mencari Sumber Gas,” J. Tek. ITS, vol. 3, no. 1, pp. F90-F95, Mar. 2014.

[9] H. Sutanto, A. D. Haryowati, and Z. Arifin, "Rancang bangun deteksi alkohol pada urine dengan sensor TGS 2620 berbasis mikrokontroler AT89S51,” Berk. Fis., vol. 13, no. 3, pp. 97-100, Mar. 2010. 